\title{
Everyday Governance of Land in Africa
}

Pierre-Yves Le Meur et Christian Lund

\section{OpenEdition}

Journals

Édition électronique

URL : http://journals.openedition.org/apad/48

DOI : 10.4000/apad.48

ISSN : 1950-6929

Éditeur

LIT Verlag

Édition imprimée

Date de publication : 1 décembre 2001

\section{Référence électronique}

Pierre-Yves Le Meur et Christian Lund, «Everyday Governance of Land in Africa », Bulletin de I'APAD [En ligne], 22 | 2001, mis en ligne le 15 décembre 2005, consulté le 07 septembre 2020. URL : http:// journals.openedition.org/apad/48; DOI : https://doi.org/10.4000/apad.48

Ce document a été généré automatiquement le 7 septembre 2020.

Bulletin de l'APAD 


\title{
Everyday Governance of Land in Africa
}

\author{
Pierre-Yves Le Meur et Christian Lund
}

1 The issue of land in Africa has a paradoxical quality. On the one hand, it is virtually omni-present in social, political and economic dynamics of competition, pursuit of interests and change. On the other hand, land is often treated as a special field in conferences, research networks and in publications (like the present one). While these are facts whose change lies outside the scope of this introduction, we are particularly pleased that the occasion of the Journées de l'APAD in Leiden in May 2002, offered the possibility to frame the issues of land within a perspective of everyday governance ${ }^{1}$. To focus on governance, not in terms of how it falls short of the index of 'good governance', but as the actual practices of how interests are pursued and countered, authority exercised and challenged, and power institutionalised and undermined, requires detailed empirical studies and is an opportunity for imaginative theorising. The perspective of land and governance contributes to a 'normalisation' of the questions land within social science research. By this we mean that land needs to be seen in its connection to other aspects of social and political life as it makes little sense in isolation. Moreover, research of 'other issues' may also do well in having an eye open for where 'land' may provide additional, complementary or contrasting explanations.

2 Through land - access to land and control over it -, social positions, power resources and moral principles are enacted and renegotiated, contributing to the reframing of the everyday governance. It is worth touching upon a few issues linking land to these processes of governance, namely the question of public authority, the question of territoriality, and the question of citizenship, in association with situated discourses of identity, belonging and inclusion/exclusion.

3 Propertied practices and representations of land rights are often caught up in practical and mundane activities of land use and transactions of transfer. However, public recognition is a constituting element of land rights, be they rights of passage, of grazing, of permanent use or of transfer. According to the law in many African societies, the recognition of rights (property rights as well as civil rights) is the 
prerogative of the state. However, in reality, broad arrays of institutions recognise claims as rights. To complicate matters, such institutions may not completely share ideas and interests about which property rights should be recognised and prevail. Moreover, the overlap with what the state (itself multiple sites of authority) recognises is, at best, partial. Furthermore, state agents often resort to non-state informal repertoires, or "administrative custom", in order to solve - or "calm down" - disputes, making things even more intricate (Le Meur 1999). The processes of recognition of rights are thus not merely a technical one, but profoundly a question of politics. However, the questions at stake go beyond who gets what right; the question of the authority to grant and enforce land rights in an everyday process, is just as pressing. In fact, the process of recognition of property rights by a politico-legal institution simultaneously constitutes a process of recognition of the legitimacy of this institution (Lund 2002). Moreover, there is no necessary causality at play. Cause and effect in the relationship between authority and land tenure may work both ways. Authority is not only a prerequisite for the granting of rights, successful granting of rights is equally an avenue to authority. This may explain why so many institutions (such as various government departments, NGO's, chieftaincy, to mention but a few) operate in this field and why politicisation of land is so persistent (Le Meur 2002a). In this respect, one does not merely observe a two-sided institutional landscape with on the one hand, various actors competing for access to rights and, on the other hand, politico-legal institutions competing for authority over land rights control and enforcement. Other instances acts as intermediaries - as institutional and political brokers - between both sides, bridging - and controlling - gaps between them by manipulating strategic information and translating cultural codes (Nauta, Faye for NGOs cases in South Africa and Senegal; Lund 1999, Tidjani Alou 2001, for cases of judicial brokerage in Burkina Faso and Niger). Economic brokerage is also part and parcel of the rapidly growing land transactions markets in rural Africa (see Zougouri for Burkina Faso, Benjaminsen \& Lund, 2003 for cases on Mali, Burkina Faso, Tanzania, and Rwanda).

Land tenure easily lends itself to ambitions of governance. This is partly explained by land's propinquity to territoriality. Many institutions of public authority frame their cause and raison d'être in terms of space. The nation state is, par excellence, an institution that expresses its reach in territorial terms. Borders and maps, administrative outposts and other representatives of the nation state like schools etc. convey a territorial representation of the state. In that respect, Boutinot's historical presentation of the Senegalese forest administration exemplify the territorial dimension of state anchoring. Nevertheless, as she shows us, this is by no way a smoothly linear process: contradictions of interests and representations arise between competing administrative and political actors, reinforced by the segmentary and non co-ordinated functioning of international development agencies and by conflicting interpretations of the decentralisation. Decentralisation can be also conceived of as a territorialized form of public policy, even though the modes of articulation between land and decentralisation vary greatly from one country to another (Toulmin 2000 ; see also Mathieu et al. 1996). Lentz uses the metaphor of Pandora box to describe its unexpected effects in North-western Ghana. She addresses the connected issues of the spatial delimitation of administrative units and of the social delimitation of local political communities, and stresses the tensions between ethnic and territorial criteria in defining local citizenship. 
The logic of the emerging modern state may well have been to make space, people and resources legible in order to govern. However, while territorial delimitation, national identity and legibility may be institutionalised to correspond to nation states, their monopolies on these processes are as precarious as their monopoly on the exercise of public authority. A wide variety of non-state institutions equally manifest themselves in terms of territory and turf. The mobilisation behind home-town associations (Trager $2001)$ and chief candidates (Berry 2001), the memberships of the vigilante groups (Gore \& Pratten 2002) or religious fraternities are often based on claims of common identity, and the organisations' everyday activities often expressed in terms of space. The territorial delimitation is important in the self-image of the concerned actors as an element of contrast to 'the State', the 'centre' - the 'up-there'. Co-existence of multiple public authorities, produce multiple, partly overlapping, territories, established as places as meaning is attached to otherwise rather inert spatial widths, distances and points. The same space may figure in a government development plan, be a church sponsored development co-operative's parish of intervention, be the realm of the sultan, the home-region of intellectuals in the capital, the fief of a local politician and the turf of the vigilantes of the hood. These institutions often have territorial markers in space, ranging from national flags over signboards, fences, party banners, masks, and marches to graffiti on walls. They may exercise public authority simultaneously, sometimes complementary, sometimes in conflict. Resurrecting historical regions, rectifying territorial mistakes, electing a canton chief, and patrolling the town by night and day, are all processes which turn space into place. That is, it turns it into someone's place. Not necessarily exclusively, but exclusion often features when land is seen as territory. This is precisely the type of story Nauta tells us about. The area of Mooifonteen farm - later Gasela community - was subject to different forms of territorial and political incorporation, from the white settlers' agrarian colonisation, labour migrations, and later the deepening of apartheid through the creation of Bantustans, to, the various phases of the post apartheid land policy, NGOs brokerage actions and 'strategic translations' and the Gasela Residents Association's claims.

6 The questions of authority and territoriality in relation to land also raise questions of citizenship. Often, people's social identity may entitle them, if not to land outright, then at least to claim it. This means that social identities and the question of citizenship become contested, and that seemingly simple and clear categories such as 'first comers' and 'late comers' become the objects of intense negotiation and conflict (Kuba et al. 2001). One can have stayed put 'forever' and yet remain a 'legal minor' in terms of rights. This is a fate that often befalls women, pastoralists, descendants of migrants and other politically weak groups. Migrants often need a willing sponsor to be able to settle in a particular place. Such relationships are normally maintained by the settlers' symbolic payment of a nominal fee or a small portion of the annual harvest. Relationships between a sponsor and a settler are often passed on through generations. However, as land has increasingly become precarious and valuable the classical relationships between autochthonous and migrants are challenged. Conversely, one can be successful in building up a status of autochthony and citizenship. Tax payment and successful participation in local politics may efface otherwise rigid boundaries. The status as autochthonous is not guaranteed once and for all either. Individuals or whole sections of a population may thus be 'down graded' or out-classed if power relations and political circumstance conjugate in particular ways (Boni 2002), an extreme case of 
this being the progressive institutionalisation of apartheid in South Africa (Mamdani 1996: 62 et seq., Chanock 2001). Categories of citizenship, commoners and nobles, ethnic or regional loyalties etc. create a friction which challenges legislation, custom and practice alike. And just as in the case of authority, there is no necessary relationship between land and citizenship. While membership in a group may entitle one to legitimate claims to land, effective land holding, wealth or numbers, may also entitle people to claim citizenship or the benefits of it. Furthermore, national citizenship interacts with various patterns of local citizenships, this interplay contributing to an on-going reshaping of the politics of belonging, land access and nation-building (Chauveau 2000, Le Meur 2002b).

Thus, the linkages between governance and land are many - many more than we have listed here - but the causality between them is contextual and culturally constructed. Here lies probably some of the reason for the dynamic character of the everyday governance of land in Africa

\section{BIBLIOGRAPHIE}

Benjaminsen Tor A., Lund C. (eds.), 2003, Securing Land Rights in Africa. London: Frank Cass. Berry S., 2001, Chiefs Know their Boundaries. Essays on Property, Power, and the Past in Asante, 1896-1996. Portsmouth \& Oxford : Heinemann \& James Currey.

Boni S., 2002, Indigenous Blood and Forest Labor: The 'Ancestralisation' of Landrights in the West African Forest Belt. Paper presented to the international workshop "Landrights and the Politics of Belonging in West Africa”, Frankfurt University, October 3-5, 2002.

Chanock M., 2001, The Making of the South African Legal Culture. Fear, Favour and Prejudice. Cambridge. Cambridge University Press.

Chauveau J.P., 2000, "Question foncière et construction nationale en Côte d'Ivoire". Politique Africaine 78 : 94-125.

Gore C., Pratten D., 2002, The Politics of Plunder : The Rhetoric of Order and Disorder in Southern Nigeria. Paper presented to the APAD Conference "The governance of daily life in Africa", Leiden African Studies Centre, 22-25 May, 2002.

Kuba R., Lentz C., Werthmann K. (eds.), 2001, Les Dagara et leurs voisins : histoire du peuplement et relations interethniques au sud-ouest du Burkina Faso. Frankfurt am Main, J.W. Goethe Universität, Berichte des Sonderforschungsbereiches 268.

Le Meur P.Y., 1999, “Coping with Institutional Uncertainty : Contested Local Public Spaces and Power in Rural Benin”. Afrika Spectrum 34 (2): 187-211.

Le Meur P.Y., 2002a, "Trajectories of the Politicisation of Land Issues. Case Studies from Benin". In : Juul, Kristine et Christian Lund (eds.) Negotiating Property in Africa, Portsmouth, Heinemann: 135-155. 
Le Meur P.Y., 2002b, "Do Chiefs know their Boundaries? Land, Migration and Autochtony in Central Benin". Paper presented to the international workshop Landrights and the Politics of Belonging in West Africa, Frankfurt University, October 3-5.

Lund C., 1999, “A Question of Honour: Property Disputes and Brokerage in Burkina Faso”. Africa 69 (4): 575-594.

Lund C., 2002, "Negotiating property institutions. On the symbiosis of property and authority in Africa.". In: Juul, K. and C. Lund (eds.) Negotiating Property in Africa, Portsmouth, Heinemann: 11-44.

Mamdani M., 1996, Citizen and Subject. Contemporary Africa and the Legacy of the Late Colonialism. Princeton. Princeton University Press.

Mathieu P. L., P-J., Willame J.C. (eds.) 1996, "Démocratie, enjeux fonciers et pratiques locales en Afrique. Conflits, gouvernance et turbulences en Afrique de l'Ouest et centrale". Cahiers Africains 23-24, Paris-Bruxelles: L'Harmattan-CEDAF.

Tidjani A. M., 2001, "La justice au plus offrant. Les infortunes du système judiciaire en Afrique de l'Ouest (autour du cas du Niger)". Politique Africaine 83 (special issue : La corruption au quotidien, G. Blundo et J-P Olivier de Sardan eds.) : 59-78.

Toulmin C., 2000, "Decentralisation and Land Tenure". In: Toulmin, C. \& J. Quan (eds.) Evolving Land Rights, Policy and Tenure in Africa, London, DFID-IIED-NRI: 229-245.

Trager L., 2001, Yoruba Hometowns. Community, Identity, and Development in Nigeria. Boulder : Lynne Rienner Publishers.

\section{NOTES}

1. In addition to the papers collected for the present issue of APAD Bulletin, the other contributors to the panel, led by Pierre-Yves Le Meur and Jean-Pierre Chauveau, were Charles J.K. Latham (Nyika vanhu: The land is the people-An examination of natural resource management in Zimbabwe), Christian Lund (Who owns Bolgatanga? Issues of urban property in northern Ghana), Amadou Keita (Les pratiques foncières à Bancoumana (Mali). Comment l'État et les populations jouent à cache-cache), and Mariatou Koné (Côte d'Ivoire: Corruption, faveurs et clientélisme autour d'enjeux fonciers à Bodiba (centre-ouest), Zahia (centre-ouest) et Bounoua (sud)). We thank them here warmly for the rich debates we had, as well as JeanPierre Chauveau who introduced the discussion in an inspiring way.

\section{AUTEURS}

\section{PIERRE-YVES LE MEUR}

Johannes Gutenberg University of Mainz, Department of Anthropology and African Studies Forum 6 D-55099 Mainz (Germany). 


\section{CHRISTIAN LUND}

International Develop. Studies, Dld. 51 Roskilde University, D-4000 Roskilde, Denmark. 